Jahangirnagar University J. Biol. Sci. 6(2): 59-66, 2017 (December)

\title{
Evaluation of seed-borne fungi associated with tomato and their control measures
}

\author{
Raihan I. Raju* \\ Department of Botany, Jahangirnagar University, Savar, Dhaka-1342, Bangladesh
}

\begin{abstract}
A number of seed borne fungi such as- Fusarium moniliforme, Curvularia lunata, Alternaria solani, Helminthosporium solani, Aspergillus flavus, A. niger and Penicillium spp. were identified from the selected BARI-8, Nilima, Patharkuchi, Roma and Ratan varieties of tomato seeds. The highest $(2.53 \%)$ mean incidence of the fungi $F$. moniliforme were recorded in tomato variety Roma, BARI- 8 , Nilima and Ratan while the lowest $(0.13 \%)$ mean incidence of the fungi Penicillium was found in Ratan. The maximum percent of germination (64\%) was recorded in both BARI-8 and Patharkuchi varieties, while the minimum $(7 \%)$ germination in Nilima. The highest seedling vigor index (632.96) was encountered in BARI-8 and the lowest in Nilima. Trichoderma viride, T. harzianum and T. koningii were used as bio-control agents against major seed borne fungi. $T$. viride showed the significantly effective mycelial growth inhibition against $F$. moniliforme and $C$. lunata, while T. harzianum and T. koningii showed poor performance against both tested fungi. In case of botanical extracts, Lawsonia inermis exhibited the maximum $(82.15 \%$ and $86.24 \%)$ inhibition of mycelium growth of $F$. moniliforme and C. lunata, respectively. Chemical fungicides, Bavistin $(0.5 \mathrm{gm} / \mathrm{l})$ inhibited $65 \%$ mycelial growth against $F$. moniliforme, while higher concentration of chemical fungicide gave $81 \%$ inhibition of $C$. lunata. The results suggested that, $L$. inermis phytoextract can possibly be exploited for the management of seed-borne pathogenic fungi of tomato in an environmental friendly way.
\end{abstract}

Key words: Antagonistic fungi, botanical extracts, seed borne fungi, tomato seeds.

\section{INTRODUCTION}

Tomato (Lycopersicon esculentum Mill) is one of the most important and popular vegetable in the world under the family Solanaceae, due to its taste, high nutritive value and diversified use (Alam et al., 1996). In Bangladesh, the average tomato production is around 100350.24 tons per annum with maximum production was 255430 tons in 2012 (Hossain and Abdulla, 2015). Infected seeds play a key role in the dissemination of plant pathogens and disease establishment (Agarwal, 1981). Over 200 diseases have been reported to affect the tomato plants in the world. At least 10 different fungi have been reported as seed-borne on tomato from different parts of the world (Ahmed et al., 1993). Six seed borne fungal diseases of tomato viz. early blight (Alternaria solani Sorauer), germination reduction (Aspergillus flavus Link, Penicillium spp.), seed discoloration (A. fumigates Fresen), Fusarium wilt (Fusarium oxysporum Schltdl), and late blight (Phytophthora infestans (Mont.) de Bary) have been detected in Bangladesh. F. oxysporum f. sp. lycopersici leading to serious yield losses (60\% to 70\%) in tomato (Kirankumar et al., 2008).

\footnotetext{
* Corresponding author. E-mail: raihan1792@gmail.com
} 
Use of good seeds can contribute to increase germination as well as vegetable yield as high as 30\% remaining all other factors of production as content (Hamim et al., 2014). Seed borne diseases create a great loss to the production of crops in Bangladesh. In order to reduce the loss, farmers use to treat seeds with chemicals (Bagga \& Sharma, 2006). Indiscriminate use of chemicals for controlling diseases of crop plants resulted environmental pollution, health hazards etc., all over the world. Trichoderma spp. became popular biological agents to protect crops against plant pathogens all over the world (Howell, 2003). Extracts of many higher plants have been reported to exhibit antifungal properties under laboratory trails (Mohana et al., 2011; Parekh et al., 2009). Exploitation of plant metabolites in crop protection and prevention of bio deterioration caused by fungi appear to be promising. Therefore, the present research has been undertaken to detect the seed-borne fungi associated with five selected varieties of tomato and assess the efficacy of biological control agents against major seed-borne pathogenic fungi of tomato as compare to chemical fungicides.

\section{MATERIALS AND METHODS}

Seeds of five different tomato varieties such as BARI-8, Nilima, Patharkuchi, Roma and Ratan were collected from local market of Savar and Laboratory of Plant Breeding and Crop Improvement, Department of Botany, Jahangirnagar University and used as materials in this investigation. The experiments were conducted in Mycology, Plant Pathology and Crop Protection Laboratory, Department of Botany, Jahangirnagar University, Savar, Dhaka, during the period of December-March, 2014.

Isolation and identification of seed-borne pathogens: Direct isolation method was performed for isolation of fungal pathogens from the selected seeds of tomato. This method consisted of incubation of seeds in humid chamber with surface sterilization following Standard Blotter Method (ISTA, 2003). Identification of isolated fungi were done following the Manuals- Dematiaceous Hypomycetes (Ellis, 1971) and Illustrated genera of imperfect fungi (Barnett \& Hunter, 1998).

Germination test and determination of vigor index: This experiment was done by using standard Paper Towel Method (ISTA, 2003). Germination rate were expressed in percentage by the following formula-

Germination rate $=\frac{\text { Total number of germinated seed }}{\text { Total number of experimental seed }} \times 100$

The vigor of the seedlings was determined using following formula-

Vigor index $=($ Mean of root length + Mean of shoot length $) \times$ Percentage of seed germination.

Fungal growth inhibition using antagonistic fungi: Mycelial growth inhibition of $F$. moniliforme and $C$. lunata by $T$. viride, $T$. harzianum and $T$. koningii was determined using duel culture technique and percentage of mycelial growth inhibition was calculated using following formula- 


$$
\mathrm{I}=\frac{C-T}{C} \times 100
$$

Where, $\mathrm{I}=$ Percentage of mycelium growth inhibition; $\mathrm{C}=$ Growth in control; $\mathrm{T}=$ Growth in treatment.

Fungal growth inhibition using botanical extracts: Methanolic extract of Lawsonia inermis and Datura stramonium were used against $F$. moniliforme and $C$. lunta to check that if fungal growth can be checked with these or not. Botanical extract of L. inermis and D. stramonium were made by adding $20 \mathrm{ml}$ of methanol in the morter and pressing and squeezing $4 \mathrm{gm}$ of fresh leaves with a clean pastle. The extract was then filtered with a muslin cloth and stored in a tube for use. The percent mycelial growth inhibitions of selected fungi were calculated following standard formula as described earlier.

Chemical control: Two commercially available fungicides viz. Bavistin (Carbendazin $50 \%$ DF) and Indofil (Mancozeb $75 \%$ WP) were tested in vitro to evaluate their efficacy on colony growth by poison food technique (Dhingra and Sinclair, 1985). Requisite quantity of fungicides were added to the medium to having concentrations of $0.5 \mathrm{gm} / \mathrm{l}$, $1.00 \mathrm{gm} / 1$ and $2.00 \mathrm{gm} / 1$ for Bavistin and $1.00 \mathrm{gm} / 1,2.00 \mathrm{gm} / 1$ and $3.00 \mathrm{gm} / 1$ concentrations for Indofil. The percent mycelial growth inhibition of treated fungi was calculated as described earlier.

\section{RESULTS AND DISCUSSION}

Seed health test: Maximum fungal infected seeds were recorded in BARI-8 (20\%) which was followed by Roma (11.33\%), Nilima (3.33\%), Patharkuchi (2\%) and Ratan (1.33\%), respectively (Fig. 1). Seed-borne fungi, i.e., Fusarium moniliforme, Curvularia lunata, Alternaria solani, Helminthosporium solani, Aspergillus flavus, Aspergillus niger, Penicillium spp. were isolated from the selected varieties of tomato seeds. Among the identified pathogenic fungi only $F$. moniliforme were found in four varieties of tomato except Patharkuchi variety. The maximum mean percent incidence of seed borne fungi were recorded as $2.53 \%$ for $F$. moniliforme, followed by A. flavus $(1.73 \%)$, C. lunata (0.79\%), A. solani and A. niger $(0.66 \%)$, H. solani $(0.4 \%)$ and Penicillium spp. $(0.13 \%)$ (Table 1). The highest and lowest incidence of fungi recorded as $20 \%$ and $1.34 \%$ for the variety BARI-8 and Ratan, respectively. Our findings are inconformity with previous results. Aspergillus, Cladosporium and Fusarium genera was found as the most common seed borne fungi on tomato seeds (Ismael, 2010). Similarly, A. flavus, A. niger, C. lunata, Fusarium spp. and $A$. solani had been detected in tomato seeds by many researchers (Hamim et al., 2014). The above experiment ensured that the identified fungal pathogens are responsible to cause seed-borne disease. 


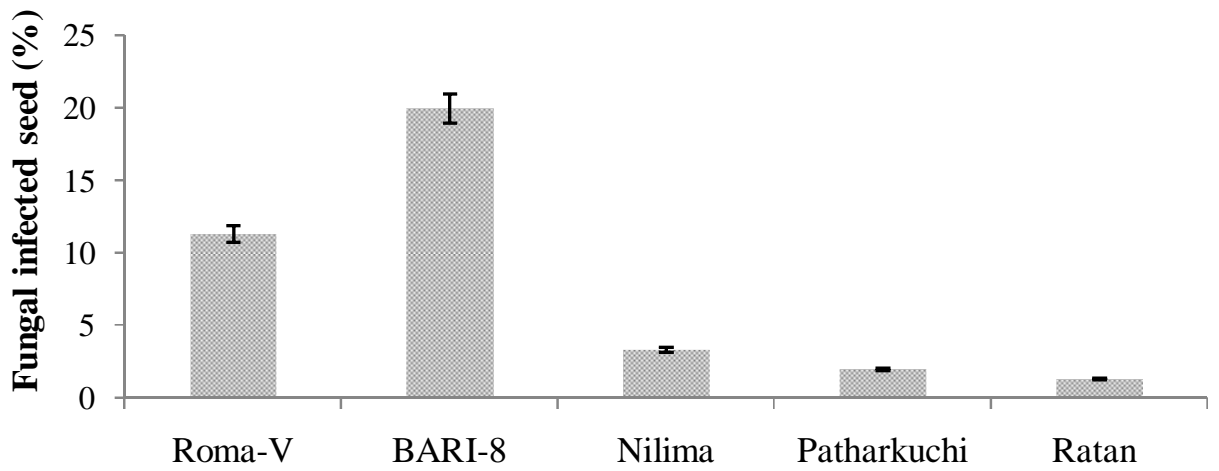

Tomato varieties

Fig. 1. Percentage of seed infection in five different varieties of tomato

Table 1. Percent incidence of seed-borne fungi in five different varieties of tomato

\begin{tabular}{|c|c|c|c|c|c|c|}
\hline \multirow[b]{2}{*}{ Seed-borne fungi } & \multicolumn{5}{|c|}{ Variety } & \multirow{2}{*}{$\begin{array}{c}\text { Mean \% } \\
\text { incidence } \\
\text { of fungi }\end{array}$} \\
\hline & Roma & BARI-8 & Nilima & Patharkuchi & Ratan & \\
\hline Fusarium moniliforme & 4.00 & 5.33 & 2.67 & - & 0.67 & 2.53 \\
\hline Curvularia lunata & 2.67 & 1.33 & - & - & - & 0.79 \\
\hline Alternaria solani & 1.33 & 2.00 & - & - & - & 0.66 \\
\hline Helminthosporium solani & - & - & - & 2.00 & - & 0.40 \\
\hline Aspergillus flavus & - & 8.67 & - & - & - & 1.73 \\
\hline Aspergillus niger & 0.67 & 2.67 & - & - & - & 0.66 \\
\hline Penicillium spp. & - & - & - & - & 0.67 & 0.13 \\
\hline Total & 8.67 & 20.00 & 2.67 & 2.00 & 1.34 & 6.90 \\
\hline
\end{tabular}

'-' not detected.

Germination rate and determination of vigor index: Seed samples of five tomato varieties were subjected to germination test in which the higher limits of germination were $64 \%$ in both BARI-8 and Patharkuchi varieties for which the corresponding vigor index were 632.64 and 602.18, respectively (Table 2) and the lower limits of germination were $7 \%$ in Nilima variety for which the corresponding vigor index were 16.66. Similarly, earlier findings indicated the germination percentage of $59.5 \%$ and vigor index of 612.85 in tomato varieties (Hamim et al., 2014). In present study, germination rates were $15 \%$ and $39 \%$ for which corresponding vigor index were 57.92 and 186.26 for Roma and Ratan, respectively. C. lunata, F. moniliforme and A. solani were found as pathogenic fungi which significantly reduce the percent seed germination. 
Table 2. Percentage of seed germination and seedling vigor in five different varieties of tomato

\begin{tabular}{l|c|c|c|c}
\hline Tomato varieties & $\begin{array}{c}\text { Seed germination } \\
\text { percentage }(\%)\end{array}$ & $\begin{array}{c}\text { Mean root length } \\
(\mathrm{cm})\end{array}$ & $\begin{array}{c}\text { Mean shoot } \\
\text { length }(\mathrm{cm})\end{array}$ & Vigor index \\
\hline Roma & 15.00 & 2.41 & 1.45 & 57.90 \\
BARI-8 & 64.00 & 6.65 & 3.24 & 632.96 \\
Nilima & 07.00 & 1.74 & 0.64 & 16.66 \\
Patharkuchi & 64.00 & 5.79 & 3.62 & 602.24 \\
Ratan & 39.00 & 2.49 & 2.28 & 186.03 \\
\hline
\end{tabular}

Antagonistic activity of Trichoderma spp. against tested fungi: $T$. viride, T. harzianum and $T$. koningii were used as antagonistic fungi against $F$. moniliforme and $C$. lunata. Results indicated that the highest $(60.92 \%)$ mycelium growth inhibitions of $F$. moniliforme were exhibited by $T$. viride, while the lowest (34.62\%) by T. harzianum after 7 days of incubation (Fig. 2). T. koningii showed variable results against mycelium growth inhibition of F. moniliforme (36.92\%) and C. lunata (35.78\%). A similar trend of mycelium growth inhibition was observed in case of $C$. lunata due to T. Viride. T. harzianum exhibited mycelium growth inhibition of $38.35 \%$ and $34.62 \%$ against $C$. lunata and $F$. moniliforme, respectively. Our result is harmonic with the work of earlier study (Jat \& Agalave, 2013) who found that Trichoderma spp., inhibited the mycelial growth of $F$. moniliforme, $F$. oxysporum and $C$. lunata. Our results also supported by earlier worker who reported that $T$. viride, $T$. harzianum and $T$. hamatum able to reduce significant disease incidence caused by fungal pathogens, i.e., Fusarium spp., Rhizoctonia solani, Pythium spp. (Tran, 2010). Similarly, Trichoderma spp. were reported to reduce disease incidence in tomato caused by $F$. solani and $F$. oxysporum (Akrami and Yousefi, 2015).

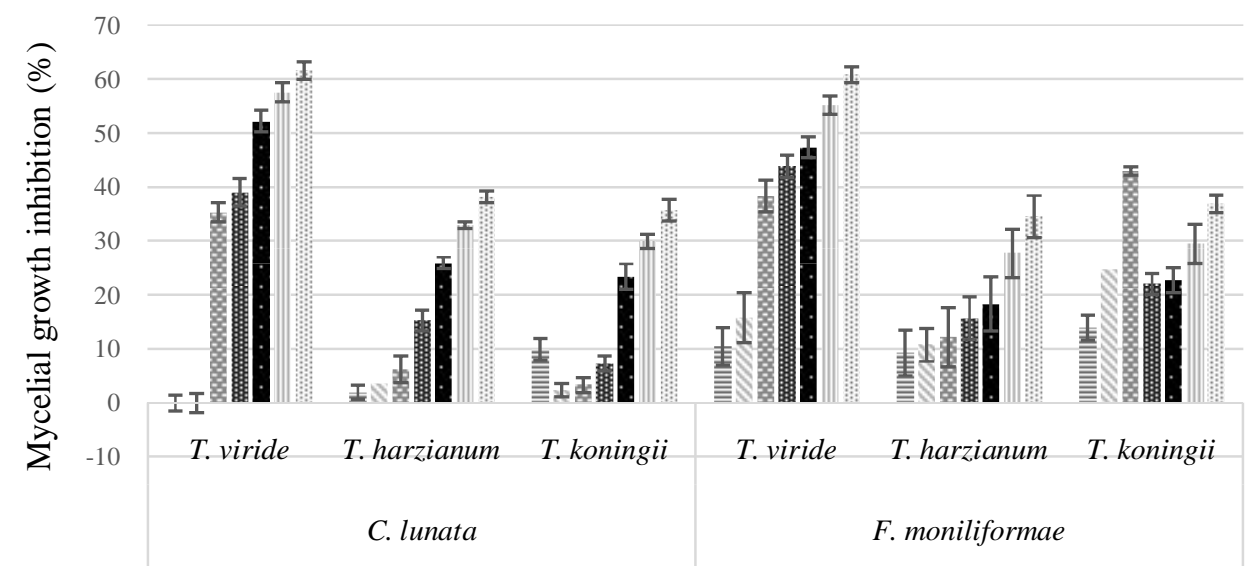

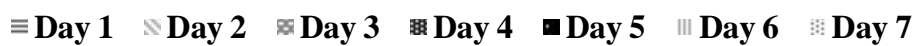

Fig. 2. Antagonistic effect of Trichoderma spp. on mycelia growth inhibition of $F$. moniliforme and C. lunata 
Efficacy of botanical extracts against tested fungi: The results of the efficacy of botanical extract against $F$. moniliforme and $C$. lunata have been presented in Fig. 3. After 7 days of incubation, L. inermis showed the maximum $82.15 \%$ and $86.24 \%$ inhibition of mycelium growth against $F$. moniliforme and $C$. lunata, respectively. On the other hand, D. stramonium exhibited $58.23 \%$ and $49.36 \%$ mycelium growth inhibition against $F$. moniliforme and $C$. lunata, respectively after 7 days of incubation. Our results supported by earlier works (Mohana et al., 2011) who found that, botanical extract of $L$. inermis was able to inhibit mycelial growth of $C$. lunata and $F$. moniliforme as $64.6 \%$ and $81.4 \%$, respectively. It has been found that the botanical extract of $L$. inermis interfere with the metabolic activity of the fungi and inhibit the production of catalase in F. oxysporum (Khan \& Nasreen, 2010).

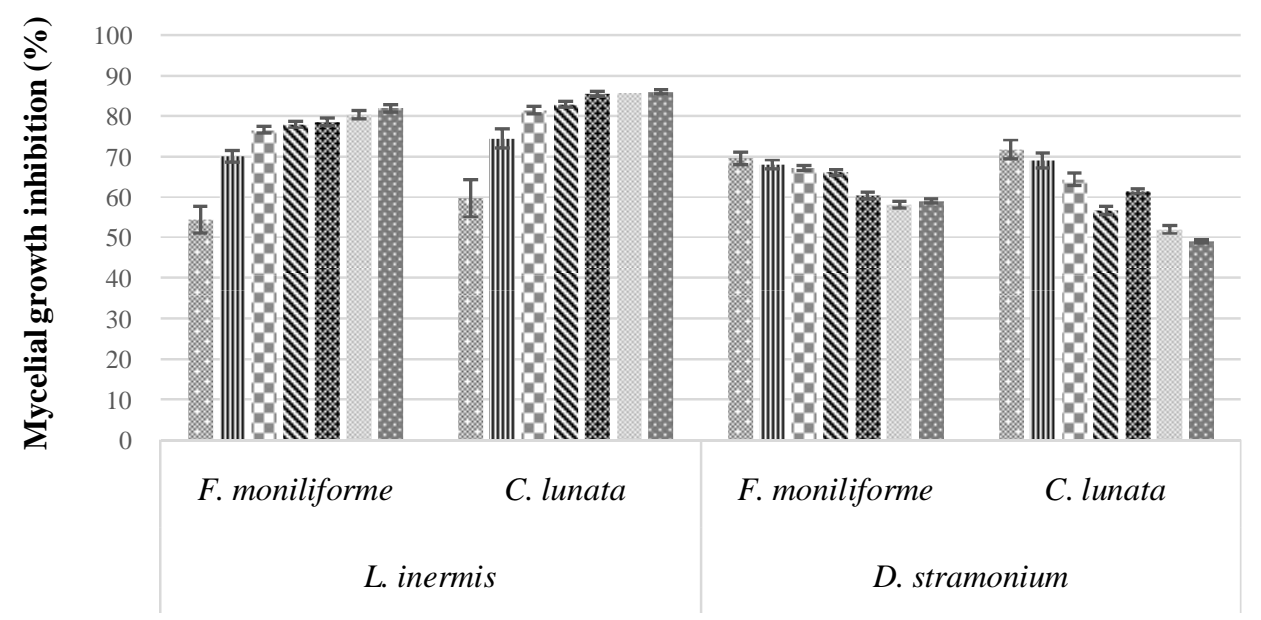

Day 1 Dal 2 Day 3 NDay 4 Day 5 Day 6 Day 7

Fig. 3. Comparative effect of $L$. inermis and $D$. stramonium leaf extract on percent mycelium growth inhibition of $F$. moniliforme and $C$. lunata

In vitro evaluation of chemical fungicides on the mycelium growth of tested fungi: The results of laboratory evaluation of chemical fungicides on the mycelium growth of $F$. moniliforme and $C$. lunata have been presented in Fig. 4. Among the three concentrations of Bavistin, the lower dose $(0.5 \mathrm{gm} / \mathrm{l})$ showed the maximum $(65.08 \%)$ inhibition of mycelium growth of $F$. moniliforme, after 7 days of incubation. Similarly, earlirer worker also found that Bavistin perform better mycelial growht inhibition of $F$. moniliforme (Mohana et al., 2011), F. oxysporum (Mamun et al., 2016; Rajput et al., 2006) and F. solani (Maitlo et al., 2015). In case of $C$. lunata, the maximum (50.46\%) mycelium growth inhibition was reported due to $0.5 \mathrm{gm} / \mathrm{l}$ concentration of Bavistin but comparatively lower inhibition (29.05\% and $27.23 \%)$ were observed due to $1.00 \mathrm{gm} / \mathrm{l}$ and $2.00 \mathrm{gm} / \mathrm{l}$ concentration, respectively after 7 days of incubation. All of the three concentrations of Bavistin used to inhibit mycelial growth of $C$. lunata were not much effective in the present experiment. Our results are in contradictory with earlier reports in 
which the higher mycelial growth inhibition of $C$. lunata due to Bavistin were found (Chowdhury et al., 2015; Mamun et al., 2016).

In case of Indofil, the higher dose $(3.00 \mathrm{gm} / \mathrm{l})$ showed the maximum $(61.54 \%)$ inhibition of mycelium growth of $F$. moniliforme, after 7 days of incubation. On the other hand, lower doses $(1.00 \mathrm{gm} / \mathrm{l})$ of Indofil showed the maximum $(81.10 \%)$ inhibition of mycelium growth of $C$. lunata. Our present findings regarding to efficacy of Indofil against $C$. lunata were conformity with previous results where $60 \%$ and $80 \%$ inhibition of radial growth of $C$. lunata at 100-400 ppm, $500 \mathrm{ppm}$ of Indofil, respectively and $65.5 \%$ inhibition of $F$. moniliforme at $500 \mathrm{ppm}$ of Indofil were observed (Chowdhury et al., 2015).

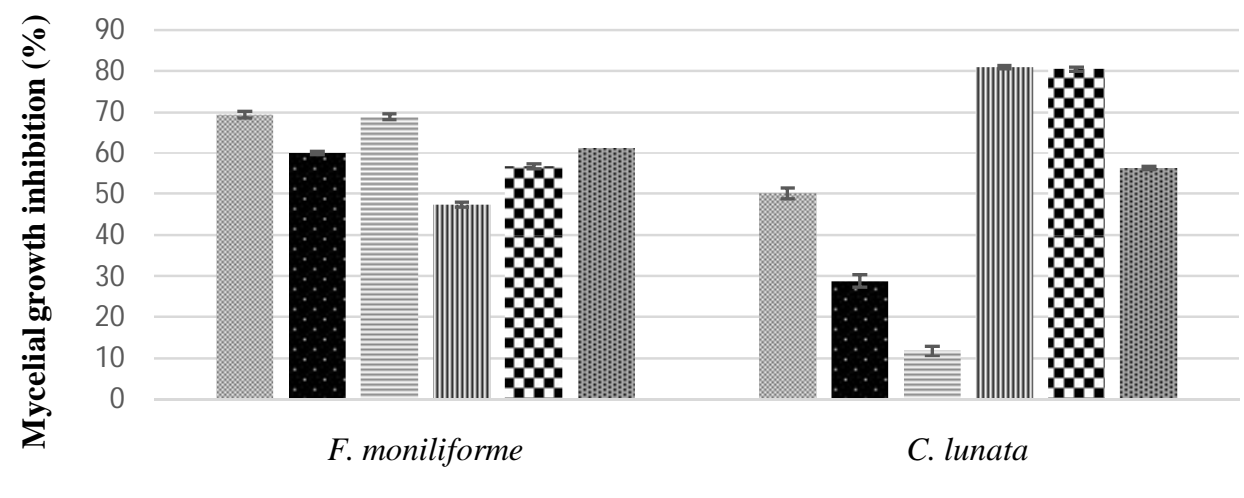

Bavistin m Bavistin $\equiv$ Bavistin III Indofil c Indofil 閏 Indofil

Fig. 4. Effect of different concentrations of Bavistin and Indofil on mycelium growth inhibition of two test pathogen after 7 days of inoculation

The findings of the present study indicate that the botanical extract of $L$. inermis showed the significant result in controlling major seed-borne fungal pathogens and it has also the strong potentiality for treating seeds of tomato in controlling seed-borne fungal diseases. However, we need to explore the active ingredient of $L$. inermis leaf which inhibited the fungal pathogens.

\section{REFERENCES}

Agarwal, V.K. 1981. Seed-borne fungi and viruses of some important crops. In: Research Bulletin, Govind Ballabh Pant University of Agriculture and Technology, India. pp. 147.

Ahmed, I., Iftikhar, S. and Bhutta, A.R. 1993. Seed-borne microorganisms in Pakistan: Checklist 1991. Pakistan Agricultural Research Council, PO Box 1031, Islamabad. pp. 32.

Akrami, M. and Yousefi, Z. 2015. Biological Control of Fusarium wilt of Tomato (Solanum lycopersicum) by Trichoderma spp. as Antagonist Fungi. Biological Forum Journal. 7(1): 887-892.

Alam, N., Akanda, A.M. and Khair, A. 1996. Biochemical changes of tomato due to purple vein virus. Bangladesh J. Bot. 25(1): 25-30. 
Bagga, P.S. and Sharma, V.K. 2006. Evaluation of fungicides as seedling treatment for controlling Bakanae / Foot-rot (Fusarium moniliforme) disease in Basmati rice. Indian Phytopathol. 59: $305-308$.

Barnett, H.L. and Hunter, B.B. 1998. Illustrated genera of imperfect fungi (4 ${ }^{\text {th }}$ ed.). APS Press, St. Paul, United State.

Chowdhury, P., Bashar, M.A. and Shamsi, S. 2015. In vitro evaluation of fungicides and plant extracts against pathogenic fungi of two rice varieties. Bangladesh J. Bot. 24 (2): 251-259.

Dhingra, O.D. and Sinclair, J.B. 1985. Basic Plant Pathology Methods. CRC Press, Inc., Florida, USA.

Ellis, M.B. 1971. Dematiaceous Hyphomycetes. Commonwealth Mycological Institut, Kew, Surrey, UK.

Hamim, I., Mohanto, D.C., Sarker, M.A. and Ali, M.A. 2014. Effect of seed borne pathogens on germination of some vegetable seeds. J. Phytopathol. Pest Manag. 1: 34-51.

Hossain, M. and Abdulla, F., 2015. On the production behaviors and forecasting the tomatoes production in Bangladesh. J. Agric. Econ. Dev. 4: 66-74.

Howell, C.R. 2003. Mechanisms employed by Trichoderma species in the biological control of plant diseases: the history and evolution of current concepts. Plant Dis. 87: 4-10.

Ismael, J.H.S. 2010. Isolation and identification of some fungi from certain solanaceous seeds in Sulaimania and Germian regions and their exudate effects on germination rate. Agric. Biol. J. North Am. 1: 615-619.

ISTA, 2003. International Rules for Seed Testing. Seed Health Testing Methods. International Seed Testing Association, Bassersdorf, Switzerland.

Jat, J.G. and Agalave, H.R. 2013. Antagonistic properties of Trichoderma species against oilseedborne fungi. Sci. Res. Report. 3: 171-174.

Khan, Z.S. and Nasreen, S. 2010. Phytochemical analysis, antifungal activity and mode of action of methanol extracts from plants against pathogens. J. Agric. Technol. 6(4): 793-805.

Kirankumar, R., Jagadeesh, K.S., Krishnaraj, P.U. and Patil, M.S. 2008. Enhanced growth promotion of tomato and nutrient uptake by plant growth promoting rhizobacterial isolates in presence of tobacco mosaic virus pathogen. Karnataka J. Agric. Sci. 21: 309-311.

Maitlo, W.A., Markhand, G.S., Abul-Soad, A.A., Lodhi, A.M. and Jatoi, M.A. 2015. Evaluation of various fungicides against Fusarium solani (mart.) Sacc causing sudden decline disease of Date Palm (Phoenix dactylifera L.) in Sindh, Pakistan. Pakistan J. Phytopathol. 27 (1): 713.

Mamun, M.A., Shamsi, S. and Bashar, M.A. 2016. In vitro evaluation of fungicides and plant extracts against pathogenic fungi of jute seeds. Bioresearch Communications. 2(1): 189192.

Mohana, D.C., Prasad, P., Vijaykumar, V. and Raveesha, K. 2011. Plant extract effect on seedborne pathogenic fungi from seeds of paddy grown in Southern India. J. Plant Prot. Res. 51: 101-106.

Parekh, J., Karathia, N. and Chanda, S. 2009. Evaluation of antibacterial activity and phytochemical analysis of Bauhinia variegata 1. bark. African J. Biomed. Res. 9: 53-57.

Rajput, A.Q., Arain, M.H., Pathan, M.A., Jiskani, M.M. and Lodhi, A.M. 2006. Efficacy of different fungicides against Fusarium wilt of cotton caused by Fusarium oxysporum f. sp. vasinfectum. Pakistan J. Bot. 38 (3): 875-880.

Tran, N.H. 2010. Using Trichoderma species for biocontrol of plant pathogens in Vietnam. $J$. ISSAAS. 16(1): 17-21. 